\title{
HOUSEHOLD STRUCTURE, LEFT-BEHIND ELDERLY, AND RURAL MIGRATION IN CHINA
}

\author{
CHEN FENGBO \\ School of Economics and Management, South China Agricultural University, Guangzhou, Guangdong, People's \\ Republic of China \\ HENRY LUCAS* \\ Institute of Development Studies, Brighton, East Sussex, United Kingdom \\ GERRY BLOOM \\ Institute of Development Studies, Brighton, East Sussex, United Kingdom \\ DING SHIJUN \\ School of Public Administration, Zhongnan University of Economics and Law, Wuhan, People's Republic of China
}

\begin{abstract}
The influence of household demographic composition on rural migration in China has received limited attention. With data from a household survey in China's Sichuan and Hubei Provinces, this paper uses Probit models to explore the influence of household structure on migration decisions. It suggests that the three-generation household encourages out-migration, with the elderly playing an important role in supporting the migration of younger members by caring for their children. In contrast with earlier findings, the serious illness of an elderly member did not encourage the return of young migrants or discourage migration decisions unless the household included young children.
\end{abstract}

Keywords. China, household structure, left-behind elderly, Probit model, rural migration

JEL Classifications: J11, R23

\section{Introduction}

Rural-urban migration has been one of the key drivers of demographic change over the past two decades in China. Such population movements can be viewed from two perspectives (Wood, 1981): microeconomic and historical structural. The microeconomic model addresses the personal cost-benefit calculus

\footnotetext{
The authors acknowledge financial support from the European Union Sixth Framework Programme (grant agreement no. INCO-CT-2005-517657). The National Natural Science Foundation of China (grant no. 71173239) and the Social Science Foundation of China (grant no. 14BGL094) provided financial support in analyzing the data. This research was also supported by the Institute of Development Studies (United Kingdom), Zhongnan University of Economics and Law, and Huazhong Agricultural University. The authors thank two anonymous reviewers and the editor of Journal of Agricultural and Applied Economics for helpful comments.

${ }^{*}$ Corresponding author: e-mail: h.lucas@emeritus.ids.ac.uk
} 
executed by potential migrants as they confront rural-urban wage, employment, and amenity differentials (Todaro, 1969). The historical-structural perspective explores the factors that lead to changes in the organization of production and seeks to make explicit the mechanisms by which social, economic, and political forces directly and indirectly affect the demand for labor (Wood, 1981). Focus on household behavior can provide a bridge between these social and individual levels of analysis (Schmink, 1984). In most developing counties, labor is typically the most important asset of poor households (Scoones, 1998), and, depending on both household characteristics and the socioeconomic and institutional environment, labor migration may play a central role in an effective livelihood strategy.

Rapid economic development in China has provided rural labor with enormous opportunities for nonfarm employment if they are willing to migrate. This has resulted in substantial increases in income and diversification of income sources for rural households (De Brauw et al., 2002; Yang and Zhishui, 2003; Zhao, 1999). The literature on rural migration has largely focused on the individual characteristics of migrants. It has shown that younger males (Fan, 2003; Mu and van de Walle, 2011; Zhong and Jing, 2012), particularly those with higher levels of education (Dewen, Fang, and Guoqing, 2008; Zhao, 1997), have been most successful in gaining the benefits of migration, primarily through urban employment. In this article, we consider factors that operate at both the individual and household levels. In particular, we suggest that household demographic structure may exert a major influence on migration decisions.

There has been limited research on the relationship between household structure and migration. There is evidence that migration decisions are influenced by the collective goals of household members. From studies on seasonal migration in India, Haberfeld et al. (1999) find that migration-related decisions should be evaluated not only on the basis of utility maximization by individual migrants, but also in terms of risk reduction at the household level. In particular, the illness of some members will influence the division of labor within a household and hence migration decisions. For example, at least one study in China (Giles and $\mathrm{Mu}, 2007$ ) suggests that younger adults are less likely to migrate in search of employment when one or both parents are ill.

Although international evidence on migration may be relevant, China does exhibit a number of specific contextual factors. The transition to a market economy is relatively recent, which has resulted in extremely rapid growth, first in agricultural output and then increasingly in manufacturing. The associated demand for labor resulted in remarkable levels of internal migration, initially to work in village and township enterprises and then to seek the higher wages offered in urban areas. These workers were often young men who left behind spouses, children, and elderly parents-the liushou, or those left holding the fort (Tan, 2009). The one-child policy, introduced in 1979, reduced the burdens on 
parents in terms of child care but also limited the aggregate supply of young adults entering the labor force; led to an aging population profile; and, given the traditional emphasis on the obligations of children to their parents and the associated limited provision for institutional care of the elderly, increased the potential burden of care to be assumed by the rising generation (Zhang and Goza, 2006). It is far from evident as to how the resulting tensions between long-standing cultural expectations and economic incentives will be resolved. Finally, the traditional Chinese hukou system, which limits the provision of social services, including education and health mainly to the official place of residence, seriously limits the options of migrants, who are seen as strictly temporary workers and often live in communal accommodation, in terms of obtaining education or health care for themselves or those who might wish to accompany them (Tan, 2009).

The article proceeds as follows. Section 2 develops a conceptual framework for the analysis of the links between serious illness and labor use. We then consider the traditional model of the division of labor in Chinese rural households and, based on a review of the literature, question the extent to which this model still applies. Section 3 describes a large-scale survey of rural households in two Chinese provinces. In Section 4, data from this study are then used in Probit models to explore the influence of household demographic composition, including the number of children and number of elderly members, and the serious illness of an elderly member. Section 5 describes the model results. Finally, the conceptual framework and findings from the household survey are used to explore policy implications.

\section{Household Structure, Left-Behind Elderly, and Rural Migration}

\subsection{Internal Migration and the Household Division of Labor in Rural China}

As indicated previously, market reforms have created enormous opportunities for rural households to diversify from own-farm agricultural production into wage employment by the out-migration of one or more members, either to urban areas or other, more prosperous, rural areas (De Brauw et al., 2002; Zhao, 1999). In 2009, the number of internal migrants in China had reached 150 million (Fang, 2010).

Migration has reshaped the structure of rural populations and householdlevel demography, creating "divided households," with individuals who consider themselves to be members of the same household living in both rural and urban areas. Migration is particularly attractive for younger adult males, whereas those "left behind" are primarily older and younger household members, often the parents, children, and, to a lesser extent, wives of migrants ( $\mathrm{Mu}$ and van de Walle, 2011; Zhong and Jing, 2012). The prospects offered by urban employment are also often sufficiently attractive to persuade many married women, even 


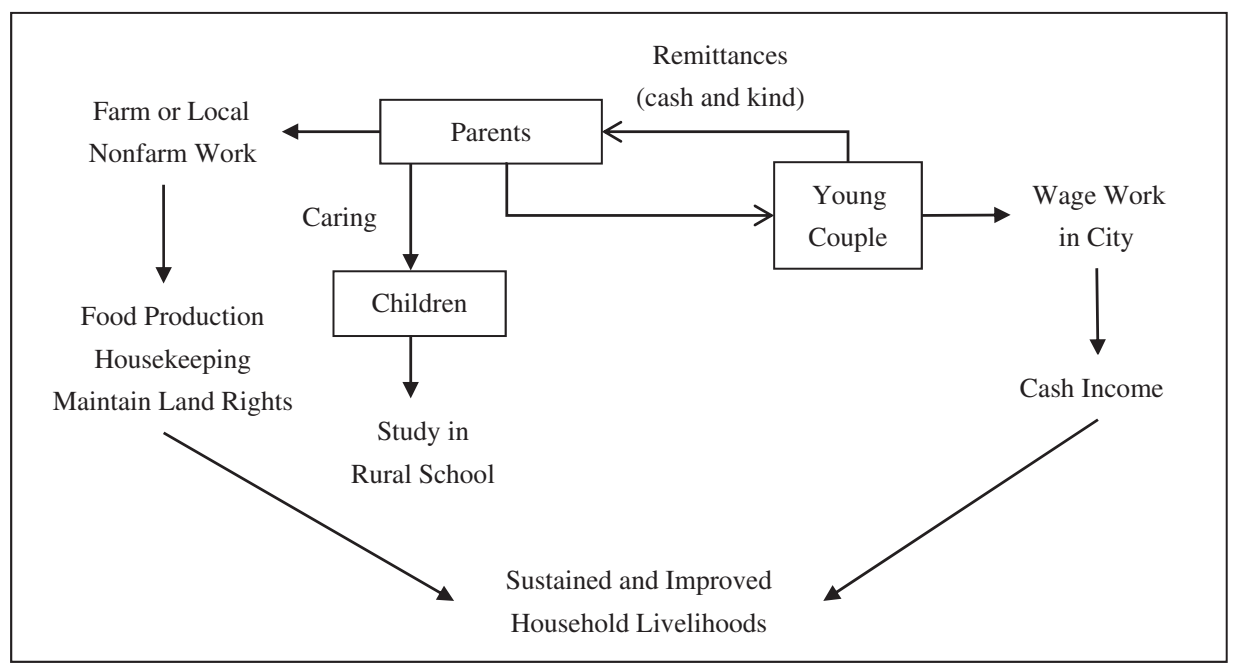

Figure 1. Positive Circle of Divided Households in Rural China

those with very young children, to join the migrant flow (Roberts et al., 2004). School-age children cannot usually accompany migrant parents. Most migrants have to live in communal hostels, and even if they can find appropriate accommodation, local governments often refuse to fund education for the children of migrants, requiring substantial "out-of-pocket" payments if those children are to be enrolled in public schools (Kwong, 2004).

Thus, a substantial proportion of rural households have adopted a livelihood strategy that involves the out-migration to urban areas of younger married couples, while their elderly parents remain in the rural area, maintaining household land rights, farming that land and taking care of grandchildren. The migrants will typically send money home and return each spring festival bringing a range of household items and consumables (Chang, Dong, and MacPhail, 2011).

The previously described livelihood strategy (Figure 1) has been adopted by a very substantial number of rural households in China and, in many cases, has dramatically increased their incomes. However, it can also be seen to have increased their vulnerability to certain types of livelihood shock or stress. For Chinese migrants, employment can often be insecure and income flows unstable (Chen, 2011; Mou et al., 2009), as most clearly demonstrated during the recent relative slowdown in economic growth. Loss of migrant incomes for households that have become dependent on those incomes can be a devastating livelihood shock. Serious illness, afflicting either migrants themselves or one of those left behind, is a common cause, necessitating a return home either to seek or provide care. Typically, migrants will only have claims on anything more than basic health services if they return to their official place of residence. 
Given that large-scale internal migration has continued for many years, a substantial proportion of the rural adult population may be returned migrants who have suffered injury or illness during urban employment or have simply grown too old to undertake the long hours of manual labor that such employment often entails (Chen et al., 2014). Given that the great majority of both the elderly and younger adults with a physical disability in rural areas have minimal access to pensions or social welfare, the household farm acts as their safety net (Fan and Wang, 2008), providing at least food, a modest income, and access to rural health services. They will typically continue to work as long as they are able (Pang, de Brauw, and Rozelle, 2004). At one level, they might be seen as a marginalized group, dependent on a limited agricultural income and remittances from migrant members of their households. However, from a household livelihoods perspective, they are very important. By maintaining the rural base, they both allow younger members, especially those with young children, to seek urban employment and also limit the risks to the household in the event that the migrants lose that employment. Indeed, they can be seen as playing an essential role in a virtuous circle that raised household living standards, reduced rural poverty, and contributed the labor that has been central to China's economic growth.

\subsection{Household Structure, Left Behind, and Rural Migration}

Historically, rural Chinese favored “joint-stem" households in which parents lived with one or more married sons and their families (Freedman et al., 1978). In more recent times, partly because of the one-child policy but also reflecting social change over the past 30 years, "three-generation" (grandparents, workingage parents, and children) and "nuclear" households (parents and children) are most common.

It would seem reasonable to expect that the presence of one or more young children in a household will substantially reduce the possibility of parental migration. In nuclear households that do decide to adopt this strategy, the husband would typically travel to seek employment, with the wife remaining in the rural area to take responsibility for child care, farmwork, and domestic activities. In three-generation households, grandparents who can care for children and maintain the rural base can facilitate migration of one or both of the younger adults. However, the sickness or disability of an elderly household member will both reduce the supply of labor and increase the demands on that labor, to the extent that they themselves require care, reducing both household productivity and incomes (Bartel and Taubman, 1979; Cropper, 1977; Schultz and Tansel, 1997). This would seem likely to decrease the possibilities for migration. Giles and $\mathrm{Mu}$ (2007) found that in general younger adults were less likely to work as migrants if one of their parents was ill. The presence of elderly household members with and without a serious illness could thus be used to test their importance in terms of migration decisions. 
In the next section, we will explore the extent to which the assumptions inherent in the previous discussion are supported by data from a large-scale sample survey in the Sichuan and Hubei Provinces of China.

\section{Data and Samples}

\subsection{Data}

The data in this article come from the POVILL (Poverty and Serious Illness) study in 2006, which was funded by the European Union. This included a household survey in Fushun County and Langzhong County in Sichuan Province and Xiaogan County and Hong'an County in Hubei Province. All these counties are officially classified as poor and have experienced the migration of their populations to the more prosperous eastern coastal regions since the end of the 1980s.

The household survey was conducted from July to August 2006, and the data were collected on 12,131 households with 50,358 members. The topics addressed in the survey included household demographic composition, economic status, health problems over the previous year, and associated coping strategies. Note that traditional definitions of the household, for example as a unit consisting of "a number of kin relations bounded by a common budget and a single cooking stove" (Croll, 1994, p. 19), have become increasingly problematic in China as the divided households described previously have become increasingly prevalent. The household survey adopted two criteria to determine household membership: having a common household registration and sharing a common budget.

\subsection{Household Characteristics}

Partly as a consequence of the one-child policy, family size in China has steadily declined and the proportion of nuclear households increased (Yuesheng, 2006). This is in line with findings from the household survey that nuclear households accounted for some $38 \%$ of the total. Three-generation households were the second most common group in rural areas, accounting for some $33 \%$ of the total (see Table 1). More than $80 \%$ of three-generation households had at least one child under the age of 16 , while this was true for some $47 \%$ of nuclear households. Couple-only and singleton households made up $17 \%$ of the total, with the great majority of members in this kind of household being over 50 years old. The remaining households accounted for $11 \%$, the most common being extended family households, those which included more distant relations.

The high proportion of three-generation households does not imply that the young couples in these households lived with their parents. Internal migration has led to a situation in which the resident population in the study areas differs radically from the population identifying themselves as household members 
Table 1. Household Demographic Composition

\begin{tabular}{lcccc}
\hline \hline & With Child under & Nobody under & \multicolumn{2}{c}{ Total } \\
\cline { 4 - 5 } Household Composition & 16 Years Old & 16 Years Old & Frequency & Percentage \\
\hline $\begin{array}{lcccc}\text { Three-generation } \\
\quad \text { household }\end{array}$ & 3,363 & 674 & 4,037 & 33.28 \\
Nuclear family household & 2,192 & 2,468 & 4,660 & 38.41 \\
Couple or single person & 0 & 2,055 & 2,055 & 16.94 \\
Others & 813 & 566 & 1,369 & 11.37 \\
Total & 6,369 & 5,761 & 12,131 & 100 \\
\hline \hline
\end{tabular}

Source: Estimated from household survey data.

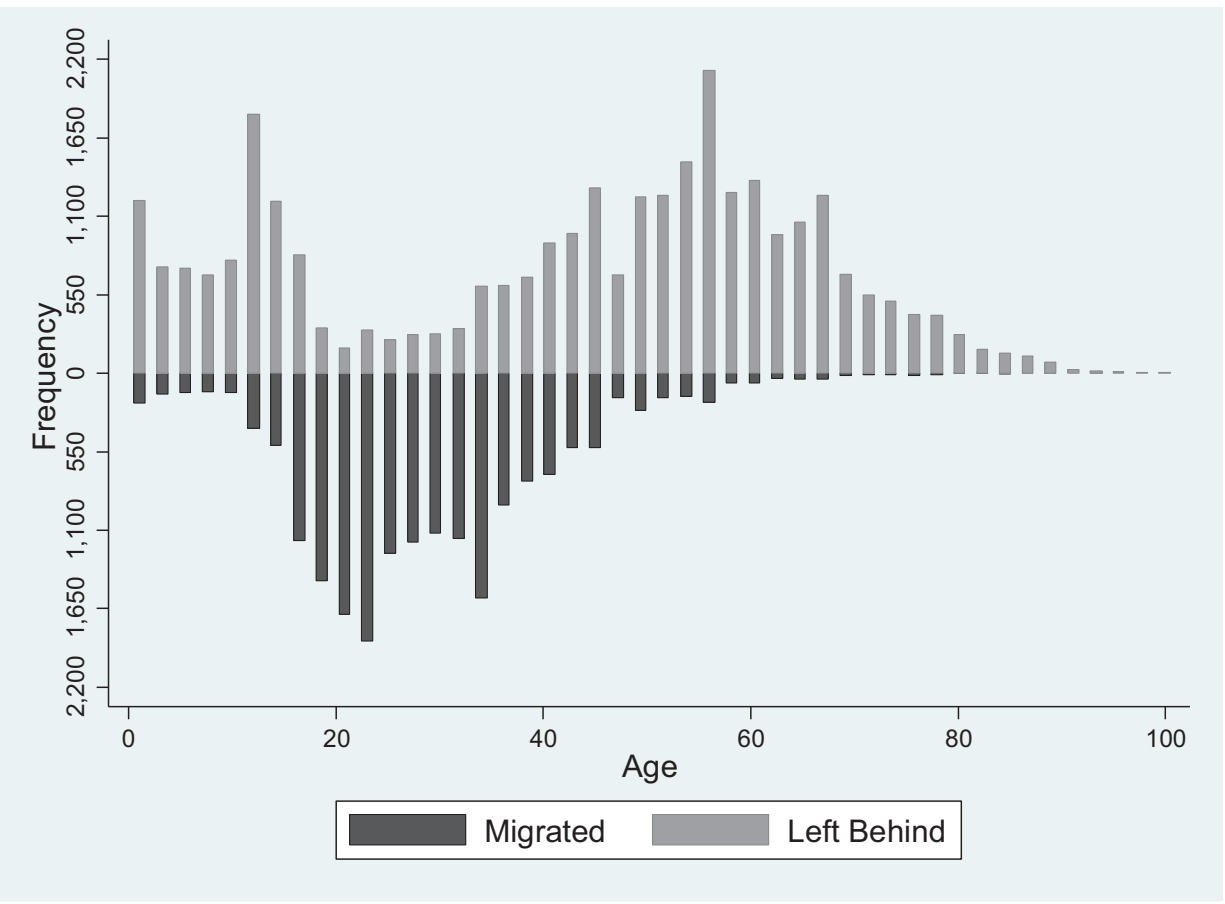

Figure 2. Population Age and Migration Status (source: estimated from household survey data)

(Figure 2). This resident population is dominated by those under $16(25 \%)$ or over $45(54 \%)$. Approximately $79 \%$ of men and $60 \%$ of women aged $16-35$ were reported as living away from home for extended periods. The average time spent away from home was about 10 months.

Migration patterns strongly influence the household division of labor (Table 2). In general, those aged 16-45 were undertaking off-farm work, primarily in urban areas, whereas those aged 45-60 identified agricultural production as their main activity. Most men over 60 saw themselves as still 
Table 2. Labor Division in Rural Households (\%)

\begin{tabular}{|c|c|c|c|c|c|c|c|c|}
\hline \multirow[b]{3}{*}{ Working Categories } & \multicolumn{8}{|c|}{ Age Groups } \\
\hline & \multicolumn{2}{|c|}{$<16$} & \multicolumn{2}{|c|}{$16-45$} & \multicolumn{2}{|c|}{$46-60$} & \multicolumn{2}{|c|}{$>60$} \\
\hline & Male & Female & Male & Female & Male & Female & Male & Female \\
\hline Agricultural work & 0.32 & 0.43 & 14.08 & 29.85 & 73.10 & 78.45 & 64.80 & 43.76 \\
\hline Nonfarm work & 1.88 & 3.27 & 66.76 & 50.70 & 14.19 & 2.49 & 1.57 & 0.47 \\
\hline Family enterprise & 0.07 & 0.02 & 4.83 & 4.06 & 4.34 & 2.38 & 1.84 & 0.66 \\
\hline Government work & 0.05 & 0.00 & 2.31 & 0.81 & 2.63 & 0.36 & 0.77 & 0.00 \\
\hline Housework & 0.11 & 0.31 & 0.55 & 6.13 & 2.47 & 13.78 & 15.00 & 34.96 \\
\hline Student & 70.35 & 71.24 & 8.84 & 6.26 & 0.00 & 0.00 & 0.00 & 0.00 \\
\hline Others & 27.22 & 24.73 & 2.64 & 2.19 & 3.27 & 2.54 & 16.01 & 20.15 \\
\hline Total & 100 & 100 & 100 & 100 & 100 & 100 & 100 & 100 \\
\hline
\end{tabular}

Source: Estimated from household survey data.

Table 3. Distribution of Reported Serious Illness across Household Members

\begin{tabular}{|c|c|c|c|}
\hline \multirow[b]{2}{*}{ Age Groups } & \multicolumn{2}{|c|}{ Frequency } & \multirow[b]{2}{*}{$\begin{array}{l}\% \text { Self-Reported } \\
\text { Serious Illness }\end{array}$} \\
\hline & $\begin{array}{l}\text { No Serious } \\
\text { Illness }\end{array}$ & $\begin{array}{l}\text { Self-Reported } \\
\text { Serious Illness }\end{array}$ & \\
\hline$<16$ & 9,168 & 734 & 7.41 \\
\hline $16-45$ & 18,571 & 3,477 & 15.77 \\
\hline $46-60$ & 7,232 & 4,848 & 40.13 \\
\hline$>60$ & 4,324 & 4,099 & 48.66 \\
\hline Total & 39,295 & 13,158 & 25.09 \\
\hline
\end{tabular}

Source: Estimated from household survey data.

primarily engaged with farmwork, though almost $15 \%$ reported that they were mainly involved in household activities. As indicated previously, the elderly population will essentially work until they are unable to do so. More than $43 \%$ of women over 60 also reported agricultural work, while approximately $35 \%$ prioritized household activities.

In this article, we focus on the impact of a serious illness suffered by an elderly household member ${ }^{1}$ on migration by younger adults. From Table 3, nearly $48 \%$ of those over 60 reported a serious illness, falling to $16 \%$ for those aged $16-45$ and $7 \%$ for children under 16 . In interpreting the high rates for those over 60 , it may be useful to note that the most common conditions related to musculoskeletal disorders, often seen by those afflicted as an inevitable consequence of the aging process, prolonged heavy manual labor, and a relatively high risk of work-related injuries.

1 In this study, the definition of serious illness had three mutually exclusive components: (1) hospitalization costs during the previous year greater than 1,000 yuan; (2) outpatient expenses over the previous year greater than 1,000 yuan; and (3) limitations on productive activities because of illness lasting longer than 3 months. 


\section{Models}

\subsection{A Probit Model of Factors Influencing Migration Decisions}

We would generally assume that individuals will try to maximize their utility by engaging in activities that maximize the return on their labor time. In an efficient labor market, that return will be primarily determined by their personal characteristics including physical health, education level, technical skills, experience, personality, and so forth. However, migration can also be seen as one possible component of the overall livelihood strategy adopted by a household in response to the opportunities and limitations imposed by the external environment (Wood, 1981). In this context, the choices made by an individual will typically be influenced by the needs and preferences of other household members. In particular, as discussed previously, the presence of young children and elderly household members may influence decisions to migrate in search of improved employment opportunities.

Probit and Tobit models could both be used to explore the relationship between the decision to migrate and individual and household characteristics. A possible dependent variable would be months of migration, which is discrete between 0 and 12. From the survey data, the histogram of this variable has a peak at 0 for nonmigrants and another at 10-11 months, with smaller percentages migrating for 1-9 months. With that kind of distribution, it becomes difficult to interpret the meaning of a marginal effect. For this reason, we find the Probit model more compelling than the Tobit model.

Following Li and Zahniser (2002), we adopt a Probit model in which it is assumed that an underlying latent variable, which in this case can be conceptualized as the gain or loss in expected utility arising from the decision to migrate, determines the likelihood of the choice that an individual will make. The value of this latent variable is determined by both individual and household characteristics. Specifically, we model the probability of choosing to migrate $\left(y_{i}=1\right)$ as follows:

$$
P\left(y_{i}=1 x_{i j}\right)=\Phi\left(\Sigma \beta_{j} x_{i j}\right) .
$$

where $\Phi$ is the cumulative distribution function of the standard normal distribution, and the $x_{i j}$ 's are the values of the independent individual and household variables for individual $i . \beta_{j}$ is vectors of independent variables. The marginal effects of each independent variable will be estimated.

\subsection{Dependent and Explanatory Variables}

Given the key role played by younger adults in household livelihood strategies, we focus here on migration decisions by younger adults, in the age group 16-45. Some $69 \%$ of this age group had been working away from home for more than 6 months at the time of the survey. In order to simplify the research, we focus on 
Table 4. Variables Considered in the Model and Their Definitions

\begin{tabular}{|c|c|}
\hline Variables & Definitions of Variables \\
\hline \multicolumn{2}{|l|}{ Independent variable } \\
\hline Migration & $1=$ Migrated $0=$ did not migrate \\
\hline \multicolumn{2}{|l|}{ Explanatory variables } \\
\hline \multicolumn{2}{|l|}{ Individual charactertics } \\
\hline Sex & $1=$ Male $0=$ female \\
\hline Age & Age of the household member making migration decision (16-45) \\
\hline Age square & Square of the above \\
\hline Marriage & $1=$ Married; $0=$ not married \\
\hline Activity & $1=$ Can do heavy work; $0=$ cannot do heavy work \\
\hline \multicolumn{2}{|l|}{ Educational level } \\
\hline Less than secondary & $1=$ Primary school or illiterate $0=$ otherwise \\
\hline Secondary & $1=$ Secondary school; $0=$ otherwise \\
\hline More than secondary & $1=$ Senior, junior, or higher education; $0=$ otherwise \\
\hline \multicolumn{2}{|l|}{ Household characteristics } \\
\hline Three-generation household & $1=$ Three-generation household; $0=$ nuclear family household \\
\hline Children number & Number of children $<16$ years in the household \\
\hline Elderly number & Number of elderly $>60$ years in the household \\
\hline Serious illness elderly number & Number of elderly $>60$ years reporting serious illness \\
\hline Province & $1=$ Hubei Province $; 0=$ Sichuan Province \\
\hline
\end{tabular}

three-generation households with one or two children (infant to under 16) and one or two elderly members (age 60 and older), and nuclear households with one or two children.

The individual characteristics considered are age, sex, marriage, education, and capacity to undertake activities. Because we expect the effects of age to be nonlinear (migration initially increasing with age but declining among older workers), we also include a quadratic term in the equation. The householdlevel characteristics considered are household structure, number of children, number of elderly, and number of elderly with serious illness. These variables are chosen based on the existing literature cited previously. Finally, we also include a dichotomous variable "Province" to allow for regional differences. Table 4 lists all the dependent and explanatory variables, and Table 5 provides descriptive statistics.

\section{Results}

\subsection{Household Demographic Profile and Migration Decisions}

We initially model the relationship between migration decisions and household composition, number of children and number of elderly, controlling for individual characteristics. Because of the significant linear correlation between the number of elderly and number of elderly with serious illness, this model does not include the latter variable. Table 6 shows the results of the Probit model. 
Table 5. Descriptive Statistics $(\mathrm{N}=20,659)$

\begin{tabular}{lrc}
\hline \hline Variables & Mean & Standard Deviation \\
\hline Dependent variables & & \\
$\quad$ Migration & 0.65 & 0.48 \\
Explanatory variables & & \\
$\quad$ Individual characteristics & & \\
$\quad$ Sex & 0.52 & 0.50 \\
Age & 30.07 & 9.13 \\
Age square & 987.42 & 554.88 \\
Marriage & 0.63 & 0.48 \\
Activity & 0.92 & 0.28 \\
Educational level & & \\
$\quad$ Less than secondary & 0.36 & 0.48 \\
$\quad$ Secondary & 0.49 & 0.50 \\
$\quad$ More than secondary & 0.16 & 0.36 \\
Household characteristics & & \\
Three-generation household & 0.48 & 0.50 \\
$\quad$ No child & 0.47 & 0.50 \\
One child & 0.36 & 0.48 \\
Two children & 0.17 & 0.37 \\
$\quad$ No elderly & 0.66 & 0.47 \\
One elderly & 0.21 & 0.41 \\
Two elderly & 0.13 & 0.34 \\
No serious illness elderly & 0.84 & 0.37 \\
One serious illness elderly & 0.14 & 0.35 \\
$\quad$ Two serious illness elderly & 0.03 & 0.16 \\
Province & 0.59 & 0.49 \\
\hline \hline
\end{tabular}

Note: We use the variables "Children number," "Elderly number," and "Serious illness elderly number" as dummy variables in this table.

As expected, these results show that a range of individual characteristics, including age, gender, marital status, capacity for activity, and education level have significant effects on the migration decision. The age variable has a positive effect on the probability, but the negative coefficient on the age-squared variable indicates that at older ages this effect reverses. As individuals reach adulthood, the likelihood of migration for work increases but then declines as they approach middle age. The effect of the gender variable reflects the traditional division of labor in Chinese rural households. Women are more likely to undertake household activities and work on the family farm, whereas men are more likely to migrate to seek employment elsewhere. The probability to migrate is significantly decreased for those who are married. As might be expected, given that they might be associated with improved employment opportunities and higher wages, superior levels of health status and education are positively associated with migration.

For the household-level characteristics, those from three-generation households were significantly more likely to migrate compared with those from 
Table 6. The Influence of Household Composition on the Migration Decision

\begin{tabular}{|c|c|c|}
\hline & \multicolumn{2}{|c|}{ Probit Model $(\mathrm{N}=20,659)$} \\
\hline & $\begin{array}{l}\text { Coefficients } \\
\text { (standard error) }\end{array}$ & $\begin{array}{l}\text { Marginal Effects } \\
\text { (standard error) }\end{array}$ \\
\hline \multirow[t]{2}{*}{ Sex } & $0.4557^{* * *}$ & $0.1612^{* * *}$ \\
\hline & $(0.0207)$ & $(0.0072)$ \\
\hline \multirow[t]{2}{*}{ Age } & $0.3834^{* * *}$ & $0.1360^{* * *}$ \\
\hline & $(0.0130)$ & $(0.0046)$ \\
\hline \multirow[t]{2}{*}{ Age square } & $-0.0065^{* * *}$ & $-0.0023^{* * *}$ \\
\hline & $(0.0002)$ & $(0.0001)$ \\
\hline \multirow[t]{2}{*}{ Marriage } & $-0.7917^{* * *}$ & $-0.2608^{* * *}$ \\
\hline & $(0.0541)$ & $(0.0160)$ \\
\hline \multirow[t]{2}{*}{ Activity } & $0.6978^{* * *}$ & $0.2679^{* * *}$ \\
\hline & $(0.0396)$ & $(0.0155)$ \\
\hline \multirow[t]{2}{*}{ Secondary } & $0.3140^{* * *}$ & $0.1108^{* * *}$ \\
\hline & $(0.0235)$ & $(0.0082)$ \\
\hline \multirow[t]{2}{*}{ More than secondary } & $0.1961^{* * *}$ & $0.0671^{* * *}$ \\
\hline & $(0.0349)$ & $(0.0115)$ \\
\hline \multirow[t]{2}{*}{ Three-generation household } & $0.6238^{* * *}$ & $0.2174^{* * *}$ \\
\hline & $(0.0352)$ & $(0.0118)$ \\
\hline \multirow[t]{2}{*}{ One child } & $-0.4174^{* * *}$ & $-0.1511^{* * *}$ \\
\hline & $(0.0244)$ & $(0.0089)$ \\
\hline \multirow[t]{2}{*}{ Two children } & $-0.5086^{* * *}$ & $-0.1912^{* * *}$ \\
\hline & $(0.0306)$ & $(0.0119)$ \\
\hline \multirow[t]{2}{*}{ One elderly } & $-0.2907^{* * *}$ & $-0.1067^{* * *}$ \\
\hline & $(0.0348)$ & $(0.0131)$ \\
\hline \multirow[t]{2}{*}{ Two elderly } & 0.0238 & 0.0084 \\
\hline & $(0.0400)$ & $(0.0141)$ \\
\hline \multirow[t]{2}{*}{ Province } & $-0.1961^{* * *}$ & $-0.0688^{* * *}$ \\
\hline & $(0.0223)$ & $(0.0077)$ \\
\hline Log (pseudo) likelihood & \multicolumn{2}{|c|}{$-10,182.4690$} \\
\hline Pseudo $R^{2}$ & \multicolumn{2}{|c|}{0.2361} \\
\hline Probability $>\chi^{2}$ & \multicolumn{2}{|c|}{0.0000} \\
\hline
\end{tabular}

Notes: Statistical significance is based on the robust standard error: ${ }^{*}, P<0.10$; ${ }^{* *}, P<0.05$; ${ }^{* * *}, P<$ 0.01. For individual education, the base category is "Less than secondary"; for number of children, the base category is "No child"; and for number of elderly, the base category is "No elderly."

a nuclear household. This supports the assumption that the elderly ${ }^{2}$ may play important roles in these households in terms of agricultural work and caring for grandchildren. On the other hand, an increase in the number of children significantly decreased the probability of migration. On average, the presence of a single elderly member in the household significantly discouraged migration, whereas in households with two elderly members there was no significant effect.

2 From the household survey data, it is common that a couple will become grandparents at around age 50 . 
Table 7. The Influence of Interaction Elderly and Child for the Migration Decision in ThreeGeneration Household (children number $\leq 2$ and elderly number $\leq 2$ )

\begin{tabular}{|c|c|c|}
\hline & \multicolumn{2}{|c|}{ Probit Model $(\mathrm{N}=10,000)$} \\
\hline & $\begin{array}{l}\text { Coefficients } \\
\text { (standard error) }\end{array}$ & $\begin{array}{l}\text { Marginal Effects } \\
\text { (standard error) }\end{array}$ \\
\hline Sex & $\begin{array}{l}0.4156^{* * *} \\
(0.0301)\end{array}$ & $\begin{array}{l}0.1246^{* * *} \\
(0.0089)\end{array}$ \\
\hline Age & $\begin{array}{l}0.4288^{* * * *} \\
(0.0209)\end{array}$ & $\begin{array}{l}0.1286^{* * * *} \\
(0.0063)\end{array}$ \\
\hline Age square & $\begin{array}{c}-0.0073^{* * *} \\
(0.0003)\end{array}$ & $\begin{array}{c}-0.0022^{* * *} \\
(0.0001)\end{array}$ \\
\hline Marriage & $\begin{array}{c}-0.4398^{* * *} \\
(0.0722)\end{array}$ & $\begin{array}{c}-0.1185^{* * *} \\
(0.0171)\end{array}$ \\
\hline Activity & $\begin{array}{l}0.6419^{* * *} \\
(0.0563)\end{array}$ & $\begin{array}{l}0.2255^{* * *} \\
(0.0218)\end{array}$ \\
\hline Secondary & $\begin{array}{l}0.2282^{* * *} \\
(0.0333)\end{array}$ & $\begin{array}{l}0.0684^{* * *} \\
(0.0100)\end{array}$ \\
\hline More than secondary & $\begin{array}{l}0.1854^{* * * *} \\
(0.0529)\end{array}$ & $\begin{array}{l}0.0527^{* * *} \\
(0.0142)\end{array}$ \\
\hline One child & $\begin{array}{c}-0.8422^{* * *} \\
(0.0870)\end{array}$ & $\begin{array}{c}-0.2571^{* * *} \\
(0.0263)\end{array}$ \\
\hline Two children & $\begin{array}{c}-0.9085^{* * *} \\
(0.0973)\end{array}$ & $\begin{array}{c}-0.3148^{* * *} \\
(0.0359)\end{array}$ \\
\hline One elderly member & $\begin{array}{c}-0.5177^{* * *} \\
(0.0911)\end{array}$ & $\begin{array}{c}-0.1600^{* * *} \\
(0.0286)\end{array}$ \\
\hline Two elderly members & $\begin{array}{r}-0.1733 \\
(0.0983)\end{array}$ & $\begin{array}{r}-0.0536 \\
(0.0313)\end{array}$ \\
\hline One child and one elderly member & $\begin{array}{l}0.3687^{* * *} \\
(0.1005)\end{array}$ & $\begin{array}{l}0.0993^{* * * *} \\
(0.0238)\end{array}$ \\
\hline One child and two elderly members & $\begin{array}{l}0.3072^{* * *} \\
(0.1118)\end{array}$ & $\begin{array}{l}0.0831^{* * *} \\
(0.0268)\end{array}$ \\
\hline Two children and one elderly member & $\begin{array}{l}0.3526^{* * *} \\
(0.1156)\end{array}$ & $\begin{array}{l}0.0932 * * * \\
(0.0262)\end{array}$ \\
\hline Two children and two elderly members & $\begin{array}{l}0.3115^{* * *} \\
(0.1274)\end{array}$ & $\begin{array}{l}0.0832^{* * *} \\
(0.0297)\end{array}$ \\
\hline Province & $\begin{array}{c}-0.3776^{* * *} \\
(0.0304)\end{array}$ & $\begin{array}{c}-0.1146^{* * *} \\
(0.0093)\end{array}$ \\
\hline Log (pseudo) likelihood & $-4,77$ & .2817 \\
\hline Pseudo $R^{2}$ & & 53 \\
\hline Probability $>\chi^{2}$ & 0.0 & 00 \\
\hline
\end{tabular}

Notes: Statistical significance is based on the robust standard error: ${ }^{*}, P<0.10$; $^{* *}, P<0.05$; ${ }^{* * *}, P<$ 0.01. For individual education, the base category is "Less than secondary"; for number of children, the base category is "No child"; and for number of elderly members, the base category is "No elderly."

In three-generation households, we assume that the elderly play an important role in caring for children. We, therefore, extend the model to consider interaction effects relating to the joint presence of elderly household members and children. The results (Table 7) show that on average the presence of one or 
two elderly members will significantly reduce the probability of migration. This will also be the effect of having one or two children in a household. However, where there are children and two elderly members, the probability of migration is significantly increased, supporting the assumption that the knowledge that children left behind will be adequately cared for removes an important barrier for potential migrants.

\subsection{The Effect of Serious Illness of the Elderly}

We anticipate that there may be a complex relationship between household composition, serious illness, and migration decisions. Illness typically reduces labor supply and increases labor demands, which might discourage migration. On the other hand, as discussed previously, illness also typically reduces household income and increases outlays, for example to pay for care and possibly to hire labor. If migration provides an opportunity to substantially increase household income and thus offset these additional financial burdens, migration may be seen as an appropriate response to illness. It should also be remembered that the migration decision may have preceded the illness. The decision then becomes one of whether to abandon what may well be the primary source of household income in order to return home.

To simplify our exploration of these issues, we focus our attention on the most common household type in our sample, the three-generation household consisting of a couple with one or two children under 16 and their elderly parents. The results in Table 8, where we explore the effects for households with two elderly members, show that when the household has no children, the serious illness of only one elderly member has a statistically significant positive effect on the migration decision. However, for households with children, the relationship between serious illness of one or both elderly members and migration are not statistically significant.

Next, we focus on households with one elderly member. Table 9 shows that, when there are no children, the serious illness of the only elderly member has a significantly positive effect on the migration decision. However, when the household includes one or two children, the serious illness of the elderly member has a significant negative effect on the migration decision.

Combining Tables 8 and 9 would suggest that the welfare of children rather than that of elderly household members is an important factor in determining whether to migrate for younger adults. Overall, the serious illness of an elderly household member, contrary to our assumption and to the findings of Giles and $\mathrm{Mu}$ (2007), does not decrease, and in some circumstances increases, the likelihood of migration by the younger adult member. One possible explanation is the expectation that migration will increase the household income and allow the household to offset losses in productivity and meet the additional costs involved in caring for the affected member. However, when the serious illness of an elderly member limits his or her capacity to meet the needs of the children in 
Table 8. Impact of Serious Illness of Elderly Members for the Migration Decision in ThreeGeneration Households with Two Elderly Members

\begin{tabular}{|c|c|c|}
\hline & \multicolumn{2}{|c|}{ Probit Model $(\mathrm{N}=2,498)$} \\
\hline & $\begin{array}{l}\text { Coefficients } \\
\text { (standard error) }\end{array}$ & $\begin{array}{l}\text { Marginal Effects } \\
\text { (standard error) }\end{array}$ \\
\hline Sex & $\begin{array}{l}0.3154 * * * \\
(0.0596)\end{array}$ & $\begin{array}{l}0.0884^{* * *} \\
(0.0167)\end{array}$ \\
\hline Age & $\begin{array}{l}0.3184^{* * *} \\
(0.0414)\end{array}$ & $\begin{array}{l}0.0891^{* * *} \\
(0.0116)\end{array}$ \\
\hline Age square & $\begin{array}{c}-0.0053^{* * *} \\
(0.0006)\end{array}$ & $\begin{array}{c}-0.0015^{* * *} \\
(0.0002)\end{array}$ \\
\hline Marriage & $\begin{array}{r}-0.1285 \\
(0.1559)\end{array}$ & $\begin{array}{c}-0.0348 \\
(0.0407)\end{array}$ \\
\hline Activity & $\begin{array}{l}0.6395^{* * *} \\
(0.1070)\end{array}$ & $\begin{array}{l}0.2150^{* * *} \\
(0.0405)\end{array}$ \\
\hline Secondary & $\begin{array}{l}0.2474 * * * \\
(0.0663)\end{array}$ & $\begin{array}{l}0.0685^{* * *} \\
(0.0181)\end{array}$ \\
\hline More than secondary & $\begin{array}{c}0.1591 \\
(0.1021)\end{array}$ & $\begin{array}{c}0.0424 \\
(0.0258)\end{array}$ \\
\hline One child & $\begin{array}{c}-0.4083^{* * *} \\
(0.1104)\end{array}$ & $\begin{array}{c}-0.1190^{* * *} \\
(0.0333)\end{array}$ \\
\hline Two children & $\begin{array}{c}-0.4874^{* * *} \\
(0.1233)\end{array}$ & $\begin{array}{c}-0.1518^{* * *} \\
(0.0418)\end{array}$ \\
\hline Serious illness of one elderly member & $\begin{array}{c}0.2457^{* *} \\
(0.1089)\end{array}$ & $\begin{array}{c}0.0676^{* *} \\
(0.0294)\end{array}$ \\
\hline Serious illness of two elderly members & $\begin{array}{c}0.2119 \\
(0.1298)\end{array}$ & $\begin{array}{c}0.0560 \\
(0.0323)\end{array}$ \\
\hline $\begin{array}{l}\text { One child in household and serious illness of one elderly } \\
\text { member }\end{array}$ & $\begin{array}{r}-0.1568 \\
(0.1488)\end{array}$ & $\begin{array}{r}-0.0458 \\
(0.0452)\end{array}$ \\
\hline $\begin{array}{l}\text { One child in household and serious illness of two elderly } \\
\text { members }\end{array}$ & $\begin{array}{r}-0.2101 \\
(0.1844)\end{array}$ & $\begin{array}{r}-0.0632 \\
(0.0591)\end{array}$ \\
\hline $\begin{array}{l}\text { Two children in household and serious illness of one elderly } \\
\text { member }\end{array}$ & $\begin{array}{r}-0.2108 \\
(0.1730)\end{array}$ & $\begin{array}{r}-0.0633 \\
(0.0554)\end{array}$ \\
\hline $\begin{array}{l}\text { Two children in household and serious illness of two elderly } \\
\text { members }\end{array}$ & $\begin{array}{r}-0.0685 \\
(0.2275)\end{array}$ & $\begin{array}{r}-0.0197 \\
(0.0671)\end{array}$ \\
\hline Province & $\begin{array}{c}-0.2269^{* * *} \\
(0.0613)\end{array}$ & $\begin{array}{c}-0.0644^{* * *} \\
(0.0176)\end{array}$ \\
\hline $\begin{array}{l}\text { Log (pseudo) likelihood } \\
\text { Pseudo } R^{2} \\
\text { Probability }>\chi^{2}\end{array}$ & $\begin{array}{r}-1,19 \\
0.0 \\
0.0\end{array}$ & $\begin{array}{l}9.6229 \\
942 \\
000\end{array}$ \\
\hline
\end{tabular}

Notes: Statistical significance is based on the robust standard error: ${ }^{*}, P<0.10 ;{ }^{* *}, P<0.05$; ${ }^{* * *}, P<$ 0.01. For individual education, the base category is "Less than secondary"; for number of children, the base category is "No child"; for number of elderly, the base category is "No elderly"; and for number of serious illness elderly, the base category is "No serious illness elderly." 
Table 9. Impact of Serious Illness of Elderly Member for the Migration Decision in ThreeGeneration Households with One Elderly Member

\begin{tabular}{|c|c|c|}
\hline & \multicolumn{2}{|c|}{ Probit Model $(\mathrm{N}=4,055)$} \\
\hline & $\begin{array}{l}\text { Coefficients } \\
\text { (standard error) }\end{array}$ & $\begin{array}{l}\text { Marginal Effects } \\
\text { (standard error) }\end{array}$ \\
\hline Sex & $\begin{array}{l}0.4565^{* * *} \\
(0.0458)\end{array}$ & $\begin{array}{l}0.1601^{* * *} \\
(0.0157)\end{array}$ \\
\hline Age & $\begin{array}{l}0.4435^{* * *} \\
(0.0316)\end{array}$ & $\begin{array}{l}0.1562^{* * *} \\
(0.0111)\end{array}$ \\
\hline Age square & $\begin{array}{c}-0.0076^{* * *} \\
(0.0005)\end{array}$ & $\begin{array}{c}-0.0027^{* * *} \\
(0.0002)\end{array}$ \\
\hline Marriage & $\begin{array}{c}-0.3832^{* * *} \\
(0.1242)\end{array}$ & $\begin{array}{c}-0.1286^{* * *} \\
(0.0393)\end{array}$ \\
\hline Activity & $\begin{array}{l}0.6342^{* * *} \\
(0.0828)\end{array}$ & $\begin{array}{l}0.2422^{* * *} \\
(0.0326)\end{array}$ \\
\hline Secondary & $\begin{array}{l}0.2519^{* * *} \\
(0.0515)\end{array}$ & $\begin{array}{l}0.0882^{* * *} \\
(0.0179)\end{array}$ \\
\hline More than secondary & $\begin{array}{l}0.2895^{* * *} \\
(0.0812)\end{array}$ & $\begin{array}{l}0.0961^{* * *} \\
(0.0251)\end{array}$ \\
\hline One child in household & $\begin{array}{c}-0.3817^{* * *} \\
(0.0663)\end{array}$ & $\begin{array}{c}-0.1372^{* * *} \\
(0.0242)\end{array}$ \\
\hline Two children in household & $\begin{array}{c}-0.4559^{* * *} \\
(0.0825)\end{array}$ & $\begin{array}{c}-0.1697^{* * *} \\
(0.0318)\end{array}$ \\
\hline Serious illness of elderly member & $\begin{array}{l}0.2105^{* * *} \\
(0.0714)\end{array}$ & $\begin{array}{l}0.0731^{* * *} \\
(0.0244)\end{array}$ \\
\hline One child in household and serious illness of elderly member & $\begin{array}{c}-0.2729^{* * *} \\
(0.1019)\end{array}$ & $\begin{array}{c}-0.1001^{* * *} \\
(0.0386)\end{array}$ \\
\hline $\begin{array}{l}\text { Two children in household and serious illness of one elderly } \\
\text { member }\end{array}$ & $\begin{array}{c}-0.2780^{* *} \\
(0.1272)\end{array}$ & $\begin{array}{c}-0.1029^{* *} \\
(0.0490)\end{array}$ \\
\hline Province & $\begin{array}{c}-0.3722^{* * *} \\
(0.0465)\end{array}$ & $\begin{array}{c}-0.1301^{* * *} \\
(0.0160)\end{array}$ \\
\hline $\begin{array}{l}\text { Log (pseudo) likelihood } \\
\text { Pseudo } R^{2} \\
\text { Probability }>\chi^{2}\end{array}$ & $\begin{array}{r}-2,0 \\
0 \\
0 .\end{array}$ & $\begin{array}{l}6.3182 \\
919 \\
00\end{array}$ \\
\hline
\end{tabular}

Notes: Statistical significance is based on the robust standard error: ${ }^{*}, P<0.10$; $^{* *}, P<0.05$; ${ }^{* * *}, P<$ 0.01 . For individual education, the base category is "Less than secondary"; for number of children, the base category is "No child"; for number of elderly, the base category is "No elderly"; and for number of serious illness elderly, the base category is "No serious illness elderly."

the household, the parents of those children are less likely to risk leaving them behind even if this limits the income-generating potential of the household.

\section{Conclusions and Policy Implications}

In this article, we have considered the influence of household demographic composition and serious illness on the allocation of labor by rural households. 
Using Probit models, we explored the influence of individual characteristics, household demographic structure, and serious illness of an elderly family member on one key aspect of labor allocation in China-the decision by adult workers to migrate in search of higher incomes. We find that three-generation households support migration by younger adults. For households with children under 16, the presence of elderly relatives facilitates the ability of younger adults to work away from home to both enhance the economic well-being of their households and contribute to the rapid economic growth in China over the past decades. In this sense, the rural elderly population can be seen as playing a key role in that growth. However, it should be recognized that this has created enormous numbers of rural divided households, which have specific types of vulnerability to ill health and other shocks that need to be considered in the design of social support mechanisms.

Contrary to our assumption, the possibility of migration by young adults is increased, not decreased, when the elderly get a serious illness. However, this changes when there are young children who are cared for by an elderly member of the family. If that elderly person falls ill, the child's parents may need to return from their jobs.

For the rural population, migration is the most important way to benefit from China's rapid economic development, but the household structure influences migration decisions. Because a child cannot live with his or her migrant parents, the grandparents care for the child. Rural families pursue livelihood strategies through migration to create a better life for the household unit, but these might not be best for all members, especially for the elderly. The existing social support systems were not designed with split rural-urban households in mind. Among policy reforms that would make these households less vulnerable to health-related risks would be measures to enable their children to obtain an education either by permitting them to go to school in urban areas or by making it possible for them to board in rural schools (at least temporarily when a carer falls ill). Reforms would also include improvements to rural health services to strengthen their capacity to provide medical and social support to the elderly when they fall temporarily ill or become dependent on outside support. This would reduce the need for migrants to return to the countryside. Rural-urban migration has been a major source of labor needed to fuel China's economic growth. The joint efforts by three-generation households have played an important role in enabling large numbers of people to move to the cities. More could be done to protect households as they manage this move.

\section{References}

Bartel, A., and P. Taubman. "Health and Labor Market Success: The Role of Various Diseases." Review of Economics and Statistics 61,1(1979):1-8. 
Chang, H., X. Dong, and F. MacPhail. "Labor Migration and Time Use Patterns of the Left-Behind Children and Elderly in Rural China." World Development 39,12(2011): 2199-210.

Chen, C., S. Ding, S. Cook, and M. Pong. “Coming Home: The Return of Migrant Workers with Illness or Work-Related Injuries in China's Hubei and Sichuan Provinces.” United Nations Research Institute for Social Development (UNRISD) working paper 2014-5, Geneva, Switzerland: UNRISD, 2014.

Chen, J. "Internal Migration and Health: Re-examining the Healthy Migrant Phenomenon in China." Social Science \& Medicine 72,8(2011):1294-301.

Croll, E. From Heaven to Earth: Images and Experiences of Development in China. London: Routledge, 1994.

Cropper, M.L. "Health, Investment in Health, and Occupational Choice." Journal of Political Economy 85,6(1977):1273-94.

De Brauw, A., J. Huang, S. Rozelle, L. Zhang, and Y. Zhang. "The Evolution of China's Rural Labor Markets during the Reforms." Journal of Comparative Economics 30,2(2002):329-53.

Dewen, W., C. Fang, and Z. Guoqing. "Employment and Wage Determination of Rural Migrant Workers : The Role of Education and Training." China Economic Quarterly 4(2008):1131-48.

Fan, C.C. "Rural-Urban Migration and Gender Division of Labor in Transitional China." International Journal of Urban and Regional Research 27,1(2003):24-47.

Fan, C.C., and W.W. Wang. "The Household as Security: Strategies of Rural-Urban Migrants in China." Migration and Social Protection in China. R. Smyth and I. Nielsen, eds. Hackensack, NJ: World Scientific, 2008, pp. 205-43.

Fang, C. "Demographic Transition, Demographic Dividend, and Lewis Turning Point in China." China Economic Journal 3,2(2010):107-19.

Freedman, R., B. Moots, T.-H. Sun, and M.B. Weinberger. "Household Composition and Extended Kinship in Taiwan.” Population Studies 32,1(1978):65-80.

Giles, J., and R. Mu. "Elderly Parent Health and the Migration Decisions of Adult Children: Evidence from Rural China.” Demography 44,2(2007):265-88.

Haberfeld, Y., R.K. Menaria, B.B. Sahoo, and R.N. Vyas. "Seasonal Migration of Rural Labor in India." Population Research and Policy Review 18,5(1999):471-87.

Kwong, J. "Educating Migrant Children: Negotiations between the State and Civil Society." China Quarterly 180(December 2004):1073-88.

Li, H., and S. Zahniser. "The Determinants of Temporary Rural-to-Urban Migration in China." Urban Studies 39,12(2002):2219-35.

Mou, J., J. Cheng, D. Zhang, H. Jiang, L. Lin, and S.M. Griffiths. "Health Care Utilisation amongst Shenzhen Migrant Workers: Does Being Insured Make a Difference?” BMC Health Services Research 9(2009):214.

$\mathrm{Mu}, \mathrm{R}$., and D. van de Walle. "Left Behind to Farm? Women's Labor Re-allocation in Rural China.” Labour Economics 18,S1(2011):S83-97.

Pang, L., A. de Brauw, and S. Rozelle. "Working until You Drop: The Elderly of Rural China." China Journal 52(July 2004):73-94.

Roberts, K., R. Connelly, Z. Xie, and Z. Zheng. "Patterns of Temporary Labor Migration of Rural Women from Anhui and Sichuan.” China Journal 52(July 2004):49-70.

Schmink, M. "Household Economic Strategies: Review and Research Agenda." Latin American Research Review 19,3(1984):87-101. 
Schultz, T.P., and A. Tansel. "Wage and Labor Supply Effects of Illness in Côte d'Ivoire and Ghana: Instrumental Variable Estimates for Days Disabled." Journal of Development Economics 53,2(1997):251-86.

Scoones, I. "Sustainable Rural Livelihoods: A Framework for Analysis." Institute of Development Studies (IDS) working paper 72, Brighton, United Kingdom: IDS, 1998.

Tan, C. “'Left-Behind' in the Countryside: Rural Households in Gansu, China.” Master's thesis, Department of Anthropology, McGill University, Montreal, 2009.

Todaro, M.P. "A Model of Labor Migration and Urban Unemployment in Less Developed Countries.” American Economic Review 59,1(1969):138-48.

Wood, C.H. "Structural Changes and Household Strategies: A Conceptual Framework for the Study of Rural Migration." Human Organization 40,4(1981):338-44.

Yang, D., and P. Zhishui. "Migration and Poverty Reduction" [In Chinese.] China Rural Survey 5(2003):2-9.

Yuesheng, W. "The Changing Family Structure in Contemporary China: An Analysis." [In Chinese.] Social Sciences in China 1(2006):96-108.

Zhang, Y., and F.W. Goza. "Who Will Care for the Elderly in China? A Review of the Problems Caused by China's One-Child Policy and Their Potential Solutions." Journal of Aging Studies 20,2(2006): 151-64.

Zhao, Y. "Labor Migration and Returns to Rural Education in China." American Journal of Agricultural Economics 79,4(1997):1278-87.

Zhao, Y. "Leaving the Countryside: Rural-to-Urban Migration Decisions in China.” American Economic Review 89,2(1999):281-86.

Zhong, F., and X. Jing. "Demographic Transition in Rural China." Rebalancing and Sustaining Growth in China. H. McKay and L. Song, eds. Canberra, Australian Capital Territory, Australia: ANU E Press, 2012, pp. 251-63. 